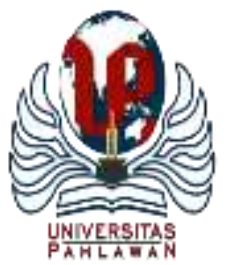

Edukatif : Jurnal Ilmu Pendidikan Volume 4 Nomor 1 Tahun 2022 Halm 443 - 455

EDUKATIF: JURNAL ILMU PENDIDIKAN

Research \& Learning in Education

https://edukatif.org/index.php/edukatif/index

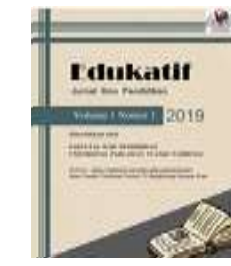

\title{
Stres Kerja dan Turnover Intention di Era Revolusi Industri 4.0: Adakah Harapan pada Kepemimpinan Transformasional?
}

\author{
Dewiana Novitasari ${ }^{1 凶}$, Muhammad Johan $^{2}$, Multi Nadeak $^{3}$, Admiral $^{4}$, Masduki Asbari ${ }^{5}$ \\ Sekolah Tinggi Ilmu Ekonomi Insan Pembangunan, Indonesia ${ }^{1,2,4}$ \\ Sekolah Tinggi Teknologi Bandung, Indonesia ${ }^{3}$ \\ STMIK Insan Pembangunan, Indonesia ${ }^{5}$ \\ E-mail : dhewiediosa@yahoo.co.id ${ }^{1}$, muhammadjohan137@gmail.com $^{2}$, multnadeak28@ gmail.com $^{3}$, \\ admiral_trust@yahoo.com ${ }^{4}$, kangmasduki.ssi@gmail.com $^{5}$
}

\begin{abstract}
Abstrak
Penelitian ini bertujuan untuk menguji pengaruh kepemimpinan terhadap turnover intention dan untuk mengetahui pengaruh mediasi stres kerja pada populasi karyawan pada industri garmen di Indonesia. Penelitian ini menggunakan metode simple random sampling terhadap 142 sampel karyawan. Hasil penelitian ini menunjukkan bahwa kepemimpinan transformasional berpengaruh negatif signifikan terhadap stres kerja dan niat berpindah karyawan. Sedangkan stres kerja berpengaruh positif dan signifikan terhadap turnover intention. Hasil penelitian ini menunjukkan bahwa hubungan antara kepemimpinan transformasional dan turnover intention secara signifikan dimediasi secara parsial oleh stres kerja, artinya kepemimpinan transformasional mengurangi stres kerja dan mengurangi turnover intention. Penelitian ini dapat membuka jalan untuk meningkatkan kesiapan pegawai dalam menghadapi era Revolusi Industri 4.0.
\end{abstract}

Kata kunci: Kepemimpinan tranformasional, stress kerja, turnover intention.

\begin{abstract}
This study aims to examine the effect of leadership on turnover intention and to investigate the mediating effect of work stress on the employee population of the garment industry in Indonesia. This study used a simple random sampling method to 142 samples of employees. The results of this study indicate that transformational leadership has a significant negative effect on job stress and employee turnover intention. Meanwhile, job stress has a positive and significant effect on turnover intention. The results of this study indicate that the relationship between transformational leadership and turnover intention is significantly mediated partially by job stress, meaning that transformational leadership reduces work stress and reduces turnover intention. This research can pave the way to improve employee readiness in the face of the Industrial Revolution 4.0 era.
\end{abstract}

Keyword: Job stress, transformational leadership, turnover intention.

Copyright (c) 2022 Dewiana Novitasari, Muhammad Johan, Multi Nadeak, Admiral, Masduki Asbari $\triangle$ Corresponding author:

Email : dhewiediosa@yahoo.co.id

DOI : https://doi.org/10.31004/edukatif.v4i1.1880

ISSN 2656-8063 (Media Cetak)

ISSN 2656-8071 (Media Online)

Edukatif : Jurnal Ilmu Pendidikan Vol 4 No 1 Tahun 2022

p-ISSN 2656-8063 e-ISSN 2656-8071 
444 Stres Kerja dan Turnover Intention di Era Revolusi Industri 4.0: Adakah Harapan pada Kepemimpinan Transformasional? - Dewiana Novitasari, Muhammad Johan, Multi Nadeak, Admiral, Masduki Asbari DOI: https://doi.org/10.31004/edukatif.v4i1.1880

\section{PENDAHULUAN}

Sumber daya manusia (SDM), tak dipungkiri menjadi faktor penentu keberhasilan organisasi dalam persaingan bisnis, apalagi setelah dunia memasuki era Revolusi Industri 4.0 (Asbari, Wijayanti, Hyun, et al., 2020). Sumber daya manusia yang berkualitas tinggi dapat terwujud jika manajemen organisasi mampu memberikan berbagai dukungan kondisi, salah satunya mengacu pada kebijakan yang diterapkan terkait dengan turnover. Turnover bisa terjadi dalam suatu organisasi dalam bentuk pengunduran diri, pemberhentian atau meninggalnya seorang anggota organisasi. Turnover terjadi karena ada faktor-faktor intensi yang memotivasi anggota organisasi untuk mengambil keputusan keluar atau pergi dari organisasi. Apa yang mendorong orang untuk mengembangkan niat meninggalkan pekerjaannya? Literatur telah mengidentifikasi berbagai alasan di balik niat keluar masuk karyawan (Shafique et al., 2018). Beberapa peneliti telah mencatat bahwa konteks sosial, seperti sejauh mana karyawan merasa didukung dan berkomitmen terhadap tempat kerja, dapat mempengaruhi niat untuk keluar dari organisasi (Asbari, Novitasari, \& Goestjahjanti, 2020; Asbari, Novitasari, Gazali, et al., 2020; Asbari \& Novitasari, 2020a, 2021a; Asbari \& Prasetya, 2021; Nazelina et al., 2020; Novitasari et al., 2021; Novitasari, Asbari, et al., 2020; Novitasari, Goestjahjanti, et al., 2020; Novitasari \& Asbari, 2020b). Studi juga menunjukkan bahwa perceived organizational support (POS), komitmen, keamanan kerja dan kepercayaan adalah anteseden utama dari niat keluar masuk karyawan (Mullen et al., 2018). Namun, sebagian besar penelitian ini telah dilakukan dilakukan dalam studi terpisah, dan dengan demikian belum memberikan gambaran yang jelas tentang bagaimana hal tersebut mempengaruhi variabel turnover intention dari karyawan secara keseluruhan. Selanjutnya mayoritas studi telah ditetapkan di negaranegara Barat. Investigasi dari anteseden dan hasil dari turnover intention lintas budaya di negara yang berbeda diperlukan untuk dinilai generalisasi temuan penelitian.

Mengingat Indonesia sebagai negara berkembang dan masih terus melakukan perbaikan di berbagai sector ekonomi, maka mengelola sumber daya manusia sebagai predictor sekaligus katalisator kinerja ekonomi menjadi penting dan genting (Asbari, 2011, 2020; Asbari et al., 2021a, 2021b; Asbari, Novitasari, Pebrina, et al., 2020; Asbari \& Novitasari, 2020b, 2021b; Jumiran et al., 2020; Lestari et al., 2020; Novitasari, Hutagalung, et al., 2020; Novitasari \& Asbari, 2020a; Sudiyono, Goestjahjanti, et al., 2020; Suprapti et al., 2020). Oleh karena itu itu, studi ini mencoba untuk mengisi kesenjangan penelitian dengan mengusulkan model integratif untuk mempelajari turnover intention karyawan di salah satu industri garmen di Indonesia. Model ini mengkaji bagaimana gaya kepemimpinan transformasional dan stress kerja dapat mempengaruhi turnover intention. Jadi, studi ini mengusulkan model perspektif karyawan tentang kepemimpinan transformasional, stres kerja yang mempengaruhi turnover intention. Penelitian ni merupakan kerja riset yang belum banyak dikaji oleh para peneliti terdahulu. Bahkan, bisa jadi studi ni merupakan yang pertama yang membahas variabel stress kerja dan kepemimpinan transformasional yang dikaitkan dengan turnover karyawan perusahaan garment di ndonesia. Semoga hasil penelitian ni, memperluas cakupan praktik dari variabel-variabel manajemen yang dibahas. Sekaligus dapat menjadi pijakan praksis bagi penelitian berikutnya. Peneliti menjelaskan metodologi secara rinci, diikuti dengan analisis dan hasil empiris. Di akhir bagian artikel ni, peneliti menyimpulkan makalah dan membahas implikasi teoritis dan praktis dihasilkan oleh studi ini.

\section{METODE}

Menurut Creswell \& Creswell (2017), jika tujuan dari penelitian ini adalah untuk mengetahui hubungan pengaruh antar variabel yang diteliti, maka pendekatan kuantitatif adalah yang terbaik. Metode penelitian kuantitatif adalah cocok dalam menguji teori dan hipotesis melalui penggunaan seperangkat alat statistik (Creswell \& Creswell, 2017). Oleh karena itu, penelitian ini menggunakan metode survei untuk menguji hipotesis yang dirumuskan. Oleh karena itu, diadopsi kuesioner digunakan sebagai instrumen untuk 
mengumpulkan data yang dibutuhkan. Populasi penelitian terdiri dari 270 karyawan sebuah industri garmen di Tangerang. Seperti yang disarankan dan diadopsi oleh penelitian sebelumnya, responden yang sesuai dari penelitian ini adalah para pengatur di perusahaan, mulai kepala regu, hingga manajer puncak, karena mereka memegang posisi kritis dalam organisasi yang memungkinkan mereka mampu memberikan informasi yang dapat dipercaya mengenai lingkungan dasar dan karakteristik organisasi mereka (Hung et al., 2010). Dengan menggunakan simple random sampling, 270 kuesioner dikirim secara online kepada populasi. 142 kuesioner dikembalikan dan valid, yang membentuk tingkat tanggapan 52.6\%. Menurut Roscoe et al. (1975) rule of thumb mengemukakan bahwa ukuran sampel adalah lebih dari 30 dan kurang dari 500 sesuai untuk sebagian besar penelitian, oleh karena itu, sampel diperoleh ukuran untuk penelitian ini dianggap sesuai.

Sifat penelitian ini melibatkan efek dependen antara konstruk laten dan variabel manifest, oleh karena itu, model pengukuran reflektif cocok untuk penelitian ini (Hair Jr et al., 2017). Semua item yang diadopsi dinilai pada skala Likert lima poin dari 1 (sangat tidak setuju) sampai 5 (sangat setuju). Turnover intention diukur dengan menggunakan tiga item (TI1-TI3) dari Cammann et al. (1979). Stres kerja diukur dengan menggunakan enam item (SK1-SK6) dari Keller (1984). Sedangkan untuk mengukur kepemimpinan transformasional, lima item (KT1-KT5) diadaptasi dari Bogler (2001).

Teknik statistik paling populer di bawah Structural Equation Model SEM adalah berbasis kovarian pendekatan (CB-SEM) dan teknik kuadrat terkecil parsial berbasis varian (PLS-SEM) (Sarstedt et al., 2014). Namun, PLS-SEM akhir-akhir ini mendapat perhatian yang luas di banyak orang disiplin ilmu seperti pemasaran, manajemen strategis, sistem informasi manajemen, dan cabang keilmuan lainnya (Hair et al., 2012). Kemampuan PLS-SEM untuk menangani permasalahan problematic modelling yang biasa terjadi di lingkungan social ilmu pengetahuan seperti karakteristik data yang tidak biasa (misalnya data non-normal) dan model yang sangat kompleks adalah alasan penting di balik peningkatan penggunaan pendekatan ini. Mengingat keuntungan dari pendekatan ini, penelitian ini menggunakan PLS-SEM untuk menguji secara keseluruhan dari hipotesis yang diajukan. Perangkat lunak SmartPLS dilakukan untuk mengevaluasi masing-masing outer model dan inner model. Pengujian outer model dilakukan untuk memastikan keandalan dan validitas pengukuran, sedangkan hipotesis yang diperkenalkan diperiksa melalui inner model. Selanjutnya, hasil akhir kuesioner yang kemudian digunakan pada penelitian ini sebagaimana disebutkan pada Tabel 1,

\section{Tabel 1}

\section{Daftar Item Penelitian}

\begin{tabular}{ll}
\hline Notasi & Item \\
\hline \multicolumn{3}{l}{ Kepemimpinan Transformasional (KT) } \\
KT1 & Pimpinan memproyeksikan dirinya sebagai panutan dan teladan \\
KT2 & Pimpinan menunjukkan bakat dan kemampuannya dalam mengatasi masalah dengan \\
& pengambilan keputusan yang tepat \\
KT3 & Pimpinan berusaha mencapai tujuan kolektif untuk memenuhi misi \\
KT4 & Pimpinan menyajikan tantangan dan proyek baru \\
KT5 & Pimpinan percaya pada kemampuan pegawainya untuk menghadapi tantangan dan \\
& hambatan \\
& \\
Stres Kerja (SK) \\
SK1 & Saya merasa lelah setelah bekerja \\
SK2 & Saya khawatir tentang masalah setelah bekerja. \\
SK3 & Saya merasa sulit untuk melepas lelah setelah bekerja \\
SK4 & Saya sering mengalami stres dan ketegangan terkait pekerjaan. \\
SK5 & Saya menganggap pekerjaan saya sangat berat dan terlalu menuntut \\
SK6 & Saya merasa lelah setelah bekerja. \\
\hline
\end{tabular}


446 Stres Kerja dan Turnover Intention di Era Revolusi Industri 4.0: Adakah Harapan pada Kepemimpinan Transformasional? - Dewiana Novitasari, Muhammad Johan, Multi Nadeak, Admiral, Masduki Asbari DOI: https://doi.org/10.31004/edukatif.v4i1.1880

\begin{tabular}{ll}
\hline Notasi & Item \\
\hline & \\
Turnover ntention (TI) \\
TI1 & Saya kemungkinan akan secara aktif mencari pekerjaan baru di tahun depan. \\
TI2 & Saya sering berpikir untuk berhenti. \\
TI3 & Saya mungkin mencari pekerjaan baru di tahun depan. \\
\hline
\end{tabular}

Maka berdasarkan kajian pustaka di atas, maka disusun dipotesis sebagai berikut:

H1: Kepemimpinan transformasional berpengaruhnegatifdan signifikan terhadap stress kerja

H2: Kepemimpinan transformasional berpengaruhnegatifdan signifikan terhadap turnoverintention

H3: Streskerja berpengaruh positifdan signifikan terhadap turnoverintention

H4: Kepemimpinan transformasional berpengaruh signifikan negatif terhadap turnover intention melalui mediasi stres kerja

Menurut penjelasan Sekaran \& Bougie (2003) kerangka teoritis merupakan landasan di mana seluruh proyek penelitian disandarkan. Dari kerangka teori ini bisa didesain hipotesis yang dapat diuji untuk mengetahui apakah kajian teori yang disusun valid atau tidak. Selanjutnya, akan dapat diuji dengan analisis statistik yang tepat dan akurat. Untuk itu, penulis membangun model penelitian sebagai mana disebut pada Gambar 1 berikut:

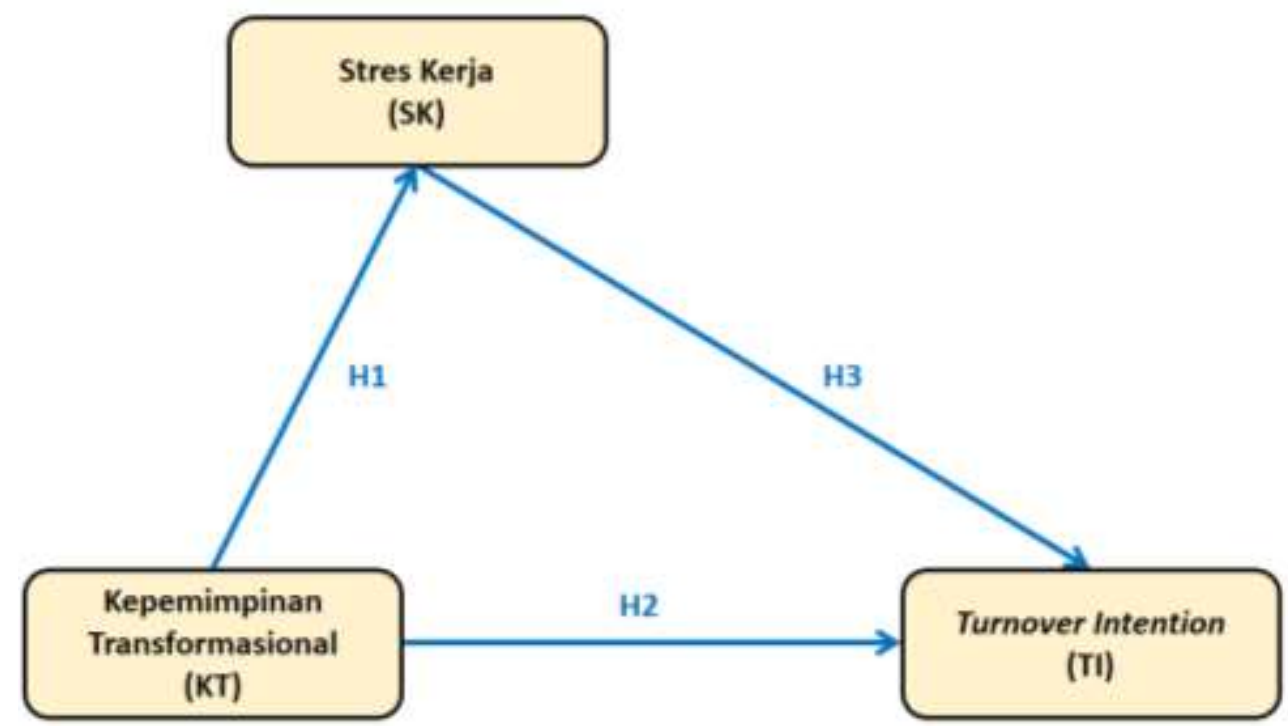

Gambar 1. Model Penelitian

\section{HASIL DAN PEMBAHASAN}

Total ada 142 karyawan yang berpartisipasi. Sebagaimana disebutkan pada table 2, responden memiliki kelompok umur yang berbeda-beda, berkisar antara di bawah usia 29 tahun (24\%), 30-49 tahun (48\%), dan lebih dari usia 50 tahun (28\%). Lama kerja mereka juga beragam, 34\% di antaranya di bawah 5 tahun, $50 \%$ sudah bekerja antara 5-10 tahun, dan 16\% sisanya telah bekerja lebih dari 10 tahun. Pendidikan tertinggi responden adalah mayoritas setingkat SLTA (SMA/SMK) yakni 75\%, dan sisanya $25 \%$ adalah lulusan sarjana.

Table 2

Deskripsi Sampel

\begin{tabular}{llll}
\hline Kriteria & & Jml. & $\%$ \\
\hline Usia & $<29$ thn. & 34 & $24 \%$ \\
& $30-49$ thn. & 68 & $48 \%$
\end{tabular}


447 Stres Kerja dan Turnover Intention di Era Revolusi Industri 4.0: Adakah Harapan pada Kepemimpinan Transformasional? - Dewiana Novitasari, Muhammad Johan, Multi Nadeak, Admiral, Masduki Asbari DOI: https://doi.org/10.31004/edukatif.v4i1.1880

\begin{tabular}{|c|c|c|c|}
\hline \multirow{3}{*}{$\begin{array}{l}\text { Masa kerja } \\
\text { sebagai karyawan }\end{array}$} & \multirow{2}{*}{$\begin{array}{l}>50 \text { thn. } \\
<5 \text { thn. }\end{array}$} & \multirow{2}{*}{$\begin{array}{l}40 \\
48\end{array}$} & \multirow{2}{*}{$\begin{array}{l}28 \% \\
34 \%\end{array}$} \\
\hline & & & \\
\hline & $5-10$ thn. & 71 & $50 \%$ \\
\hline & $>10$ thn. & 23 & $16 \%$ \\
\hline \multirow{2}{*}{ Ijazah tertinggi } & SMA & 107 & $75 \%$ \\
\hline & $\geq \mathrm{S} 1$ & 35 & $25 \%$ \\
\hline
\end{tabular}

Tahap pengujian model pengukuran meliputi pengujian validitas konvergen, validitas diskriminan. Sementara untuk menguji reliabilitas konstruk dipakai nilai cronbah's alpha dan composite reliability. Hasil analisis PLS dapat digunakan untuk menguji hipotesis penelitian jika seluruh indikator dalam model PLS telah memenuhi syarat validitas konvergen, validitas diskriminan dan uji reliabilitas. Uji validitas konvergen dilakukan dengan melihat nilai loading factor masing-masing indikator terhadap konstruknya. Pada sebagian besar referensi, bobot faktor sebesar 0,7 atau lebih dianggap memiliki validasi yang cukup kuat untuk menjelaskan konstruk laten (Chin, 1998; Ghozali, 2014; J. F. Hair et al., 2010). Pada penelitian ini batas minimal besarnya loading factor yang diterima adalah minimal 0,7, dan dengan syarat nilai AVE setiap konstruk di atas 0,5 (Ghozali, 2014). Setelah melalui pengolahan SmartPLS 3.0, seluruh indikator telah memiliki nilai loading factor di atas 0,7 dan nilai AVE di atas 0,5. Model fit atau valid dari penelitian ini dapat dilihat pada Gambar 2. Jadi dengan demikian, validitas konvergen dari model penelitian ini sudah memenuhi syarat. Nilai loadings, cronbach's alpha, composite reliability dan AVE setiap konstruk selengkapnya dapat dilihat Tabel 3.

Discriminant validity dilakukan untuk memastikan bahwa setiap konsep dari masing-masing variabel laten berbeda dengan variabel laten lainnya. Model mempunyai discriminant validity yang baik jika nilai kuadrat AVE masing-masing konstruk eksogen (nilai pada diagonal) melebihi korelasi antara konstruk tersebut dengan konstruk lainnya (nilai di bawah diagonal) (Ghozali, 2014). Hasil pengujian discriminant validity adalah dengan menggunakan nilai kuadrat AVE, yakni dengan melihat Fornell-Larcker Criterion Value diperoleh sebagaimana ditunjukkan pada Tabel 3. Hasil uji validitas deskriminan pada tabel 4 menunjukkan bahwa seluruh konstruk telah memiliki nilai akar kuadrat AVE di atas nilai korelasi dengan konstruk laten lainnya (melalui kriteria Fornell-Larcker). Demikian juga nilai cross-loading seluruh item dari suatu indikator lebih besar dari item indikator lainnya sebagaimana disebut pada Tabel 4, sehingga dapat disimpulkan bahwa model telah memenuhi validitas deskriminan (Fornell \& Larcker, 1981).

Selanjutnya dilakukan evaluasi collinearity untuk mengetahui ada tidaknya masalah collinearity pada model. Untuk menemukan collinearity tersebut, diperlukan statistik collinearity VIF dari setiap konstruk. Jika VIF lebih dari 5, maka model memiliki collinearity (Hair et al., 2014). Seperti yang ditunjukkan pada Tabel 5, semua skor VIF kurang dari 5, yakni hasil dari model struktural collinearity mengungkapkan nilai VIF di bawah 2. Hal ini menunjukkan bahwa model penelitian ini tidak ada masalah multikolinearitas.

Reliabilitas konstruks dapat dilihat dari nilai cronbach's alpha dan composite reliability pada masingmasing konstruks. Nilai composite reliability dan cronbach's alpha yang disarankan adalah di atas 0,7 (Ghozali, 2014). Hasil uji reliability pada tabel 3 menunjukkan bahwa seluruh konstruks telah memiliki nilai composite reliability dan cronbach's alpha lebih besar dari $0,7(>0,7)$. Kesimpulannya, seluruh konstruk telah memenuhi reliabilitas yang dipersyaratkan. 
448 Stres Kerja dan Turnover Intention di Era Revolusi Industri 4.0: Adakah Harapan pada Kepemimpinan Transformasional? - Dewiana Novitasari, Muhammad Johan, Multi Nadeak, Admiral, Masduki Asbari DOI: https://doi.org/10.31004/edukatif.v4i1.1880

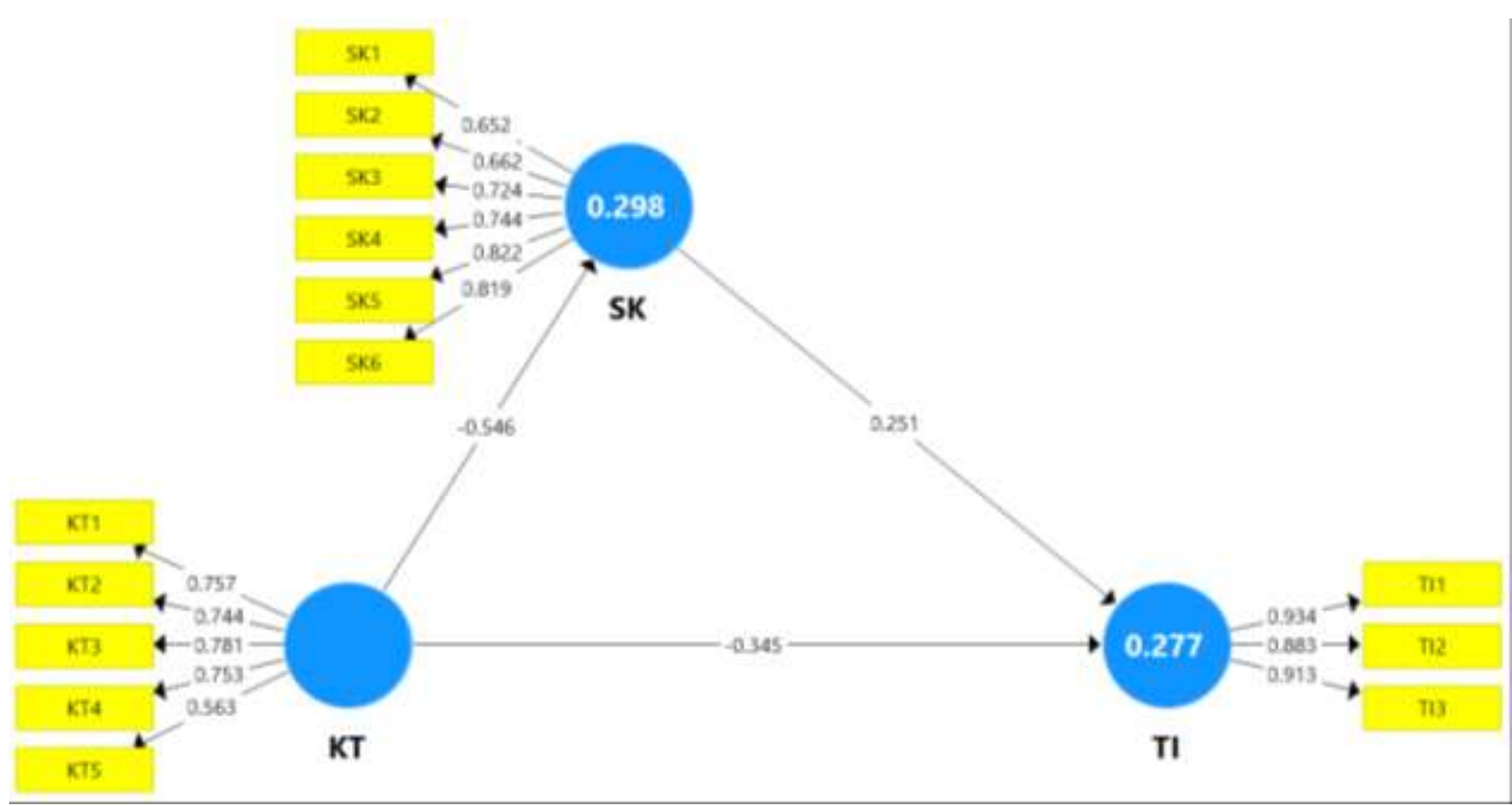

Gambar 2. Model Penelitian Valid

Sumber: Hasil Pengolahan SmartPLS 3.0 (2021)

Tabel 3

Items Loadings, Cronbach's Alpha, Composite Reliability, and Average Variance Extracted (AVE)

\begin{tabular}{llcccc}
\hline Variables & Items & Loadings & Cronbach's Alpha & Composite Reliability & AVE \\
\hline Kepemimpinan & KT1 & 0,757 & 0,770 & 0,845 & 0,524 \\
Transformasional (KT) & KT2 & 0,744 & & & \\
& KT3 & 0,781 & & & \\
& KT4 & 0,753 & & & \\
& KT5 & 0,563 & & 0,878 & \\
\hline Stres Kerja (SK) & SK1 & 0,652 & 0,836 & & \\
& SK2 & 0,662 & & & \\
& SK3 & 0,724 & & & \\
& SK4 & 0,744 & & 0,828 \\
& SK5 & 0,822 & & & \\
\hline Turnoverintention (TI) & SK6 & 0,819 & & & \\
& TI1 & 0,934 & 0,896 & & \\
& TI2 & 0,883 & & & \\
& TI3 & 0,913 & & & \\
\end{tabular}

Sumber: Hasil Pengolahan SmartPLS 3.0 (2021)

Tabel 4

Discriminant Validity

\begin{tabular}{llll}
\hline Variables & KT & SK & TI \\
\hline & & & \\
Kepemimpinan Transformasional (KT) & 0,724 & & \\
Stres Kerja(SK) & $-0,546$ & 0,740 & \\
Turnover intention (TI) & $-0,482$ & 0,440 & 0,910
\end{tabular}

Sumber: Hasil Pengolahan SmartPLS 3.0 (2021) 
449 Stres Kerja dan Turnover Intention di Era Revolusi Industri 4.0: Adakah Harapan pada Kepemimpinan Transformasional? - Dewiana Novitasari, Muhammad Johan, Multi Nadeak, Admiral, Masduki Asbari DOI: https://doi.org/10.31004/edukatif.v4i1.1880

Tabel 5

Collinearity (VIF)

\begin{tabular}{lccc}
\hline Variables & KT & SK & TI \\
\hline & & & \\
Kepemimpinan Transformasional (KT) & & 1,000 & 1,425 \\
Stres Kerja (SK) & & 1,425 \\
Turnoverintention $(\mathrm{TI})$ & Sumber: Hasil Pengolahan SmartPLS 3.0 (2021)
\end{tabular}

Tabel 6

Nilai $R$ Square

\begin{tabular}{|c|c|c|c|}
\hline \multicolumn{4}{|c|}{ Mal K square } \\
\hline & & & Square \\
\hline v ariables & Ksquare & & Adjusted \\
\hline Stres Kerja (SK) & & 0,298 & 0,293 \\
\hline Turnover intention (TI) & & 0,277 & 0,266 \\
\hline
\end{tabular}

Sumber: Hasil Pengolahan SmartPLS 3.0 (2021)

Tabel 7

Hypotheses Testing

\begin{tabular}{llccccc}
\hline Hypotheses & Relationship & Beta & SE & T Statistics & P-Values & Decision \\
\hline H1 & KT -> SK & $-0,546$ & 0,061 & 8,994 & 0,000 & Didukung \\
H2 & KT -> TI & $-0,345$ & 0,109 & 3,165 & 0,002 & Didukung \\
H3 & SK -> TI & 0,251 & 0,099 & 2,545 & 0,011 & Didukung \\
H4 & KT ->SK -> TI & $-0,137$ & 0,058 & 2,375 & 0,018 & Didukung \\
\hline
\end{tabular}

Pengujian hipotesis dalam PLS disebut juga sebagai uji inner model. Uji ini meliputi uji signifikansi pengaruh langsung dan tidak langsung serta pengukuran besarnya pengaruh variabel eksogen terhadap variabel endogen. Untuk mengetahui pengaruh kepemimpinan transformasional terhadap turnover intention melalui stress kerja sebagai variable mediasi dibutuhkan uji pengaruh langsung dan tidak langsung. Uji pengaruh dilakukan dengan menggunakan uji t-statistik dalam model analisis partial least squared (PLS) dengan menggunakan bantuan software SmartPLS 3.0, Dengan tehnik boothstrapping, diperoleh nilai $R$ Square dan nilai uji signifikansi sebagaimana Tabel 6 dan Tabel 7. Hasilnya adalah semua hipotesis di dukung.

Berdasarkan Tabel 6, nilai R Square stress kerja (SK) sebesar 0,298 yang berarti bahwa variabel stress kerja (SK) mampu dijelaskan oleh variabel kepemimpinan transformasional (KT) sebesar 29.8\%, sedangkan sisanya sebesar 70,2\% dijelaskan oleh variabel lain yang tidak dibahas dalam penelitian ini. Sementara itu, nilai R Square turnover intention (TI) sebesar 0,277 yang berarti bahwa variabel turnover intention (TI) mampu dijelaskan oleh variabel kepemimpinan transformasional (KT) dan stress kerja (SK) sebesar 27.7\%, sedangkan sisanya sebesar $72.3 \%$ dijelaskan oleh variabel lain yang tidak dibahas dalam penelitian ini. Sedangkan Tabel 7 menampilkan t-statistics dan p-values yang menunjukkan pengaruh antar variable penelitian yang telah disebutkan.

Menurut hasil studi ini, kepemimpinan transformasional mempengaruhi secara negatif signifikan tehadap stres kerja dan turnover intention. Stres terkait pekerjaan berpengaruh positif signifikan terhadap turnover intention. Pengaruh stres terkait pekerjaan terhadap turnover intention lebih rendah jika dibandingkan dengan variabel kepemimpinan transformasional. Selain itu, temuan menunjukkan bahwa stres kerja secara parsial memediasi baik hubungan antara kepemimpinan transformasional dan turnover intention. Selanjutnya, pengaruh kepemimpinan transformasional terhadap turnover intention menurun ketika stress kerja dimasukkan dalam model, yang secara parsial mengimplikasikan bahwa kepemimpinan transformasional mengurangi stres kerja, yang pada gilirannya mengurangi turnover intention. 
450 Stres Kerja dan Turnover Intention di Era Revolusi Industri 4.0: Adakah Harapan pada Kepemimpinan Transformasional? - Dewiana Novitasari, Muhammad Johan, Multi Nadeak, Admiral, Masduki Asbari DOI: https://doi.org/10.31004/edukatif.v4i1.1880

Sasaran utama dari penelitian ini adalah untuk menilai pengaruh dari beberapa persepsi dan sikap terkait pekerjaan karyawan terhadap intensi turnover mereka yang sebagian besar memiliki konsekuensi bagi organisasi perusahaan. Kepemimpinan merupakan faktor penting untuk menurunkan tingkat turnover, dan stres merupakan faktor lain yang meningkatkannya. Secara khusus dalam studi ini penulis berkonsentrasi pada pengaruh kepemimpinan transformasional terhadap pada tingkat stres dan niat keluar karyawan. Ada sejumlah penyebab stres di tempat kerja yang pada akhirnya mengakibatkan stres bagi karyawan. Oleh karena itu, manajemen beserta para pemimpin di organisasi perusahaan perlu menemukan cara untuk mengurangi konsekuensi negatif dari stres yang dirasakan karyawan. Pemimpin memiliki peran penting untuk mengurangi stres terkait pekerjaan. Perilaku pemimpin memiliki pengaruh penting terhadap perilaku karyawan (Asbari et al., 2021b; Asbari \& Novitasari, 2021b; Asbari \& Prasetya, 2021; Kamar et al., 2019; Suroso et al., 2021; Yuwono et al., 2020; Zaman et al., 2020a, 2020b). Penting bagi para pemimpin untuk mendapatkan kepercayaan dan kesetiaan bawahan mereka (Nuryanti et al., 2020). Semua harapan tersebut dapat diwujudkan oleh efektivitas praktik kepemimpinan transformasional oleh para pemimpinan organisasi. Kepemimpinan transformasional memberikan komitmen dan loyalitas karyawan (Asbari, 2019b, 2019a; Basuki et al., 2020b; Hutagalung et al., 2020; Maesaroh et al., 2020; Silitonga et al., 2020b). Ketika karyawan percaya dan loyal kepada pimpinannya, maka stres yang terkait dengan pekerjaannya akan berkurang dan mereka tidak memiliki niat yang kuat untuk keluar dari organisasi.

\section{KESIMPULAN}

Temuan studi ini mengonfirmasi bahwa kepemimpinan transformasional secara negatif mempengaruhi stres kerja dan turnover intention. Ini menyiratkan bahwa jenis kepemimpinan yang transformagtif membantu mengurangi stres dan pergantian karyawan. Temuan dan implikasi ini sebagian besar sejalan dengan literatur yang ada. Namun demikian, penelitian ini juga bukannya tanpa batasan. Tanpa menggunakan studi longitudinal, hubungan antara stres dan intensi turnover tidak dapat dipahami dengan baik dan menyeluruh tuntas. Penelitian selanjutnya tentang topik ini disarankan dan memang perlu untuk dikembangkan menjadi longitudinal. Dimungkinkan juga untuk memperluas model teoritis dengan memasukkan variabel dependen tambahan seperti komitmen organisasi, OCB, komitmen organisasi, dan atau gaya kepemimpinan lainnya.

\section{DAFTAR PUSTAKA}

Asbari, M. (2011). Kepemimpinan Transformasional: Landasan Menuju World Class Company.

Asbari, M. (2019a). Pengaruh kepemimpinan transformasional dan klim organisasi terhadap kinerja dosen. JOCE $P, 13(2), 172-186$. http://jurnal.ipem.ac.id/index.php/joce-ip/article/view/187

Asbari, M. (2019b). Pengaruh Kepemimpinan Transformasional dan klim Organisasi terhadap Kinerja Dosen. Journal Of Communication Education, 13(2), 172-186.

Asbari, M. (2020). s Transformational Leadership Suitable for Future Organizational Needs? nternational Journal of Sociology, Policy and Law (Ijospl), 1(01), 51-55.

Asbari, M., \& Novitasari, D. (2020a). Pengaruh Kesiapan untuk Berubah di Masa Pandemi Covid-19: Apa yang Dibutuhkan Pemimpin untuk Menjaga Kinerja. Jurnal Ekonomika: Manajemen, Akuntansi, Dan Perbankan Syari'ah, 9(2), 1-17. https://doi.org/https://doi.org/10,24903/je.v9i2.932

Asbari, M., \& Novitasari, D. (2020b). The Role of Readiness for Change on Part-Timer Employee Performance: Analysis of Transformational Leadership Practice n Convection ndustri. Journal of Communication Education (JOCE), 14(02).

Asbari, M., \& Novitasari, D. (2020c). The Role of Readiness for Change on Part-Timer Employee Performance: Analysis of Transformational Leadership Practice n Convection ndustri. Journal of Communication Education (JOCE), 14(02). http://jurnal.ipem.ac.id/index.php/joce-ip/article/view/220 
451 Stres Kerja dan Turnover Intention di Era Revolusi Industri 4.0: Adakah Harapan pada Kepemimpinan Transformasional? - Dewiana Novitasari, Muhammad Johan, Multi Nadeak, Admiral, Masduki Asbari DOI: https://doi.org/10.31004/edukatif.v4i1.1880

Asbari, M., \& Novitasari, D. (2021a). Pengaruh Aktivitas Berbagi Pengetahuan dan Mediasi Budaya terhadap Kemampuan novasi Guru. JMSP (Jurnal Manajemen Dan Supervisi Pendidikan), 5(1), 324-334.

Asbari, M., \& Novitasari, D. (2021b). Pengaruh Authentic Leadership terhadap Mentalitas Siap Berubah dan Kinerja Pegawai Paruh Waktu. Business Management Journal, 17(1), 73-88. https://doi.org/http://dx.doi.org/10,30813/bmj

Asbari, M., Novitasari, D., Gazali, G., Silitonga, N., \& Pebrina, E. T. (2020). Analisis Kesiapan untuk Berubah di Masa Pandemi Covid-19: Studi Pengaruh Kepemimpinan Transformasional terhadap Kinerja Karyawan. Jurnal Perspektif, 18(2), 147-159. https://ejournal.bsi.ac.id/ejurnal/index.php/perspektif/article/view/8576

Asbari, M., Novitasari, D., \& Goestjahjanti, F. S. (2020). Mempertahankan Kinerja Karyawan di Masa Pandemi Covid-19: Studi Kasus pada ndustri Ritel. JMK (Jurnal Manajemen \& Kewirausahaan), 5(3), 183-203.

Asbari, M., Novitasari, D., Pebrina, E. T., \& Santoso, J. (2020). Work-Family Conflict and Employee Performance during Covid-19 Pandemic: What s the Role of Mental Readiness to Change? JPBM (Jurnal Pendidikan Bisnis Dan Manajemen), 6(2).

Asbari, M., \& Prasetya, A. B. (2021). Managerial Coaching: Rahasia Membangun Kinerja, Komitmen Tim dan Modal Psikologis Guru. Edumaspul - Jurnal Pendidikan, 5(1), 490-506. https://ummaspul.ejournal.id/maspuljr/article/view/1248

Asbari, M., Purba, J. T., Hariandja, E. S., \& Sudibjo, N. (2021a). From Leadership to nnovation: Managing Employee Creativity. Jurnal Manajemen Strategi Dan Aplikasi Bisnis, 4(1), 143-154.

Asbari, M., Purba, J. T., Hariandja, E. S., \& Sudibjo, N. (2021b). Membangun Kesiapan Berubah dan Kinerja Karyawan: Kepemimpinan Transformasional versus Transaksional. Jurnal lmiah Manajemen Dan Bisnis, 22(1), 54-71,

Asbari, M., Wijayanti, L., Hyun, C. C., Purwanto, A., \& Santoso, P. B. (2020). How to build nnovation capability $\mathrm{n}$ the RAC ndustri to face ndustrial revolution 4.0? nternational Journal of Psychosocial Rehabilitation, 24(6), 2008-2027. https://doi.org/10,37200/IJPR/V24I6/PR260192

Bass, B. M., \& Riggio, R. E. (2006). Transformational Leadership. n Lawrence Erlbaum Associates, nc., Publishers (2nd ed.). https://doi.org/10,5742/mewfm.2017.92984

Basuki, S., Novitasari, D., Fahlevi, M., Nadeak, M., Fahmi, K., Pebrina, E. T., Sudiyono, R. N., \& Asbari, M. (2020a). Performance Analysis of Female Employees n the Covid-19 Pandemic Period: The Effects of Readiness for Change and Effectiveness of Transformational Leadership. Solid State Technology, 63(1s), 201-217. http://www.solidstatetechnology.us/index.php/JSST/article/view/709

Basuki, S., Novitasari, D., Fahlevi, M., Nadeak, M., Fahmi, K., Pebrina, E. T., Sudiyono, R. N., \& Asbari, M. (2020b). Performance Analysis of Female Employees n the Covid-19 Pandemic Period: The Effects of Readiness for Change and Effectiveness of Transformational Leadership. Solid State Technology, 63(1s), 201-217.

Bogler, R. (2001). The nfluence of leadership style on teacher job satisfaction. Educational Administration Quarterly, 37(5), 662-683. https://doi.org/10,1177/00131610121969460

Cahyono, Y., Novitasari, D., Sihotang, M., Aman, M., Fahlevi, M., Nadeak, M., Siahaan, M., Asbari, M., \& Purwanto, A. (2020). The Effect of Transformational Leadership Dimensions on Job Satisfaction and Organizational Commitment: Case Studies n Private University Lecturers. Solid State Technology, 63(1s), 158-184. http://www.solidstatetechnology.us/index.php/JSST/article/view/707

Cammann, C., Fichman, M., Jenkins, D., \& Klesh, J. (1979). The Michigan organizational assessment questionnaire. Unpublished Manuscript, University of Michigan, Ann Arbor, 71-138.

Chin, W. (1998). The Partial Least Squares Approach to Structural Equation Modeling (E. Modern Methods for Business Research, n: G. A. Marcoulides (ed.)). Lawrence Erlbaum Associates Publisher. 
452 Stres Kerja dan Turnover Intention di Era Revolusi Industri 4.0: Adakah Harapan pada Kepemimpinan Transformasional? - Dewiana Novitasari, Muhammad Johan, Multi Nadeak, Admiral, Masduki Asbari DOI: https://doi.org/10.31004/edukatif.v4i1.1880

Creswell, J. W., \& Creswell, J. D. (2017). Research design: Qualitative, quantitative, and mixed methods approaches. Sage publications.

Dimaculangan, E. D., \& Aguiling, H. M. (2012). The effects of transformational leadership on salesperson's turnover ntention. nternational Journal of Business and Social Science, 3(19).

Elçi, M., Şener, İ., Aksoy, S., \& Alpkan, L. (2012). The mpact of Ethical Leadership and Leadership Effectiveness on Employees' Turnover ntention: The Mediating Role of Work Related Stress. Procedia - Social and Behavioral Sciences, 58, 289-297. https://doi.org/10,1016/j.sbspro.2012.09.1003

Fornell, C., \& Larcker, D. F. (1981). Evaluating Structural Equation Models with Unobservable Variables and Measurement Error. Journal of Marketing Research, 18(1), 39. https://doi.org/10,2307/3151312

Ghozali, . (2014). Structural Equation Modeling, Metode Alternatif dengan Partial Least Square (PLS) (4th ed.). Badan Penerbit Universitas Diponegoro.

Goestjahjanti, S. F., Novitasari, D., Hutagalung, D., Asbari, M., \& Supono, J. (2020). mpact of Talent Management, Authentic Leadership and Employee Engagement on Job Satisfaction: Evidence From South East Asian ndustries. Journal of Critical Reviews, 7(19), 67-88. http://www.jcreview.com/?mno=101983

Hair, J. F., Black, W. C., Babin, B. J., \& Anderson, R. E. (2010). Multivariate Data Analysis (7th ed.). Pearson Prentice Hall.

Hair, Joe F, Sarstedt, M., Ringle, C. M., \& Mena, J. A. (2012). An assessment of the use of partial least squares structural equation modeling $\mathrm{n}$ marketing research. Journal of the Academy of Marketing Science, 40(3), 414-433.

Hair Jr, J. F., Sarstedt, M., Ringle, C. M., \& Gudergan, S. P. (2017). Advanced ssues $n$ partial least squares structural equation modeling. saGe publications.

Harris, G. E., \& Cameron, J. E. (2005). Multiple Dimensions of Organizational dentification and Commitment as Predictors of Turnover ntentions and Psychological Well-Being. Canadian Journal of Behavioural Science, 37(3), 159-169. https://doi.org/https://doi.org/10,1037/h0087253

Hung, R. Y.-Y., Lien, B. Y.-H., Fang, S.-C., \& McLean, G. N. (2010). Knowledge as a facilitator for enhancing nnovation performance through total quality management. Total Quality Management, 21(4), 425-438.

Hutagalung, D., Asbari, M., Fayzhall, M., Ariyanto, E., Agistiawati, E., Sudiyono, R. N., Waruwu, H., Goestjahjanti, F. S., Winanti, W., \& Yuwono, T. (2020). Peran Religiusitas, Kepemimpinan Transformasional, Kepuasan Kerja dan Mediasi Organizational Citizenship Behavior terhadap Kinerja Guru. EduPsyCouns: Journal of Education, Psychology and Counseling, 2(1), 311-326.

Iqbal, S., Ehsan, S., Rizwan, M., \& Noreen, M. (2014). The mpact of organizational commitment, job satisfaction, job stress and leadership support on turnover ntention $\mathrm{n}$ educational nstitutes. nternational Journal of Human Resource Studies, 4(2), 181, https://doi.org/10,5296/ijhrs.v4i2.5906

Jumiran, Novitasari, D., Nugroho, Y. A., Sutardi, D., Sasono, ., \& Asbari, M. (2020). Pengaruh Dimensi Kepemimpinan Transformasional terhadap Kepuasan Kerja dan Komitmen Organisasional: Studi Kasus pada Dosen Perguruan Tinggi Swasta. EduPsyCouns: Journal of Education, Psychology and Counseling, 2(1), 600-621,

Kamar, K., Novitasari, N., Asbari, M., Winanti, \& Goestjahjanti, F. S. (2019). Enhancing Employee Performance during the Covid-19 Pandemic: the Role of Readiness for Change Mentality. Jurnal Dinamika Manajemen, 11(2), 154-166. http://journal.unnes.ac.id/nju/index.php/jdm/article/view/25279

Keller, D. (1984). Humor as Therapy. WI: Med-Psych Publications.

Lestari, B., Novitasari, D., Silitonga, N., \& Asbari, M. (2020). The Effect of Recruitment and Career Development on The Spirit of Teachers' Work Performance n MTs Nurul Huda. Journal of ndustrial 
453 Stres Kerja dan Turnover Intention di Era Revolusi Industri 4.0: Adakah Harapan pada Kepemimpinan Transformasional? - Dewiana Novitasari, Muhammad Johan, Multi Nadeak, Admiral, Masduki Asbari DOI: https://doi.org/10.31004/edukatif.v4i1.1880

Engineering \& Management Research (JIEMAR), 1(2), 108-121,

Maesaroh, S., Asbari, M., Hutagalung, D., Mustofa, M., Agistiawati, E., Basuki, S., Radita, F. R., Nurasiah, N., Yulia, Y., \& Singgih, E. (2020). Pengaruh Religiusitas dan Kepemimpinan Transformasional terhadap Kinerja Guru melalui Mediasi Organizational Citizenship Behavior. EduPsyCouns: Journal of Education, Psychology and Counseling, 2(1), 276-290,

Mullen, P. R., Malone, A., Denney, A., \& Dietz, S. S. (2018). Job Stress, Burnout, Job Satisfaction, and Turnover ntention Among Student Affairs Professionals. College Student Affairs Journal, 36(1), 94 108. https://doi.org/https://doi.org/10,1353/csj.2018.0006

Nazelina, M., Novitasari, D., Fikri, M. A. A., \& Asbari, M. (2020). The Effect of Brand mage, Price and Service Quality on Consumer Decisions Using Delivery Services. Journal of ndustrial Engineering \& Management Research (JIEMAR), 1(3), 135-147.

Novitasari, D., \& Asbari, M. (2020a). Pengaruh Kepemimpinan Transformasional terhadap Kinerja Karyawan: Peran Kesiapan untuk Berubah sebagai Mediator. Jurnal Manajemen, 10(2), 84-99.

Novitasari, D., \& Asbari, M. (2020b). Urgensi Kepemimpinan dan Mentalitas Siap Berubah Terhadap Kinerja Pegawai di Musim Pandemi Covid-19. Jurnal REKOMEN (Riset Ekonomi Manajemen), 4(1), 66-80,

Novitasari, D., Asbari, M., \& Sasono,. (2021). Analisis Pengaruh Religiusitas dan Kualitas Pelayanan terhadap Kepuasan Kerja: Studi Kasus pada Karyawan ndustri Manufaktur. Jurnal Manajemen Strategi Dan Aplikasi Bisnis, 4(1), 117-130,

Novitasari, D., Asbari, M., Wijayanti, L. M., Hyun, C. C., \& Farhan, M. (2020). The Role of Religiosity, Leadership Style, Job Satisfaction and Organizational Citizenship Behavior Mediation on Woman Teachers' Performance. Solid State Technology, 63(6), 2953-2967.

http://solidstatetechnology.us/index.php/JSST/article/view/3380

Novitasari, D., Goestjahjanti, F. S., \& Asbari, M. (2020). The Role of Readiness to Change between Transformational Leadership and Performance: Evidence from a Hospital during Covid-19 Pandemic. APMBA (Asia Pacific Management and Business Application), 9(1), 37-56. https://doi.org/10,21776/ub.apmba.2020,009.01,4

Novitasari, D., Hutagalung, D., Nugroho, Y. A., Pramono, T., Asbari, M., Nuryanti, Y., \& Yuwono, T. (2020). Does Genetic Personality and Parenting Style nfluence Students' Character Building? Journal of Critical Reviews, 7(19), 119-129.

Nuryanti, Y., Novitasari, D., Nugroho, Y. A., Fauji, A., Gazali, \& Asbari, M. (2020). Meningkatkan Komitmen Organisasional Dosen: Analisis Pengaruh Kepemimpinan Perguruan Tinggi dan Kepuasan ntrinsik \& Ekstrinsik Dosen. EduPsyCouns: Journal of Education, Psychology and Counseling, 2(1), 561-581,

Robbins, S. P., \& Judge, T. A. (2013). Organizational Behavior. Pearson Education nc.

Roscoe, A. M., Lang, D., \& Sheth, J. N. (1975). Follow-up Methods, Questionnaire Length, and Market Differences $n$ Mail Surveys: $\mathrm{n}$ this experimental test, a telephone reminder produced the best response rate and questionnaire length had no effect on rate of return. Journal of Marketing, 39(2), 20-27.

Sarstedt, M., Ringle, C. M., Smith, D., Reams, R., \& Hair Jr, J. F. (2014). Partial least squares structural equation modeling (PLS-SEM): A useful tool for family business researchers. Journal of Family Business Strategy, 5(1), 105-115.

Sekaran, U., \& Bougie, R. (2003). Research Methods For Business: A Skill Building Approach (Sixth edit). John Wiley and Sons, nc.

Shafique, ., N Kalyar, M., \& Ahmad, B. (2018). The nexus of ethical leadership, job performance, and turnover ntention: The mediating role of job satisfaction. nterdisciplinary Description of Complex Systems: NDECS, 16(1), 71-87. 
454 Stres Kerja dan Turnover Intention di Era Revolusi Industri 4.0: Adakah Harapan pada Kepemimpinan Transformasional? - Dewiana Novitasari, Muhammad Johan, Multi Nadeak, Admiral, Masduki Asbari DOI: https://doi.org/10.31004/edukatif.v4i1.1880

Shareef, R. A., \& Atan, T. (2019). The nfluence of ethical leadership on academic employees' organizational citizenship behavior and turnover ntention: Mediating role of ntrinsic motivation. Management Decision.

Silitonga, N., Novitasari, D., Sutardi, D., Sopa, A., Asbari, M., Yulia, Y., Supono, J., \& Fauji, A. (2020a). The Relationship of Transformational Leadership, Organizational Justice and Organizational Commitment: a Mediation Effect of Job Satisfaction. Journal of Critical Reviews, 7(19), 89-108. http://www.jcreview.com/?mno=101999

Silitonga, N., Novitasari, D., Sutardi, D., Sopa, A., Asbari, M., Yulia, Y., Supono, J., \& Fauji, A. (2020b). The Relationship of Transformational Leadership, Organizational Justice and Organizational Commitment: a Mediation Effect of Job Satisfaction. Journal of Critical Reviews, 7(19), 89-108.

Singgih, E., skandar, J., Goestjahjanti, F. S., Fahlevi, M., Nadeak, M., Fahmi, K., Anwar, R., Asbari, M., \& Purwanto, A. (2020). The Role of Job Satisfaction $n$ the Relationship between Transformational Leadership, Knowledge Management, Work Environment and Performance. Solid State Technology, 63(2s), 293-314. http://www.solidstatetechnology.us/index.php/JSST/article/view/1556

Sudiyono, R. N., Fikri, M. A. A., Asbari, M., Suroso, Nugroho, Y. A., \& Singgih, E. (2020). The Role of Employee Engagement $\mathrm{n}$ the Relationship between Authentic Leadership , Talent Management and Job Satisfaction. nternational Journal of Advanced Science and Technology, 29(5), 11809-11836. http://sersc.org/journals/index.php/IJAST/article/view/25377

Sudiyono, R. N., Goestjahjanti, F. S., Asbari, M., Agistiawati, E., Fayzhall, M., Yani, A., Winanti, W., Yuwono, T., Nurasiah, N., \& Yulia, Y. (2020). Meningkatkan Komitmen dan Kinerja Dosen: Apa Peran Manajemen Perguruan Tinggi? EduPsyCouns: Journal of Education, Psychology and Counseling, 2(1), $337-352$.

Sun, R., \& Wang, W. (2017). Transformational leadership, employee turnover ntention, and actual voluntary turnover n public organizations. Public Management Review, 19(8), 1124-1141,

Suprapti, S., Asbari, M., Cahyono, Y., \& Mufid, A. (2020). Leadership Style, Organizational Culture and nnovative Behavior on Public Health Center Performance during Pandemic Covid-19. Journal of ndustrial Engineering \& Management Research, 1(2), 76-88.

Suroso, Riyanto, Novitasari, D., Sasono, ., \& Asbari, M. (2021). Esensi Modal Psikologis Dosen: Rahasia Kreativitas dan novasi di Era Education 4.0, Edumaspul - Jurnal Pendidikan, 5(1), 437-451 https://ummaspul.e-journal.id/maspuljr/article/view/1240

Sutardi, D., Novitasari, D., Asbari, M., Silitonga, N., Nugroho, Y. A., Hutagalung, D., Mustofa, Chidir, G., Basuki, S., \& Yuwono, T. (2020). Pengaruh Work-Family Conflict, Stres Kerja dan Social Support terhadap Kepuasan Kerja: Studi Kasus pada Guru Wanita di Tangerang. EduPsyCouns: Journal of Education, Psychology and Counseling, 2(1), 482-498. https://ummaspul.e-journal.id/Edupsycouns/article/view/513

Yang, H.-C., Ju, Y.-H., \& Lee, Y.-C. (2016). Effects of job stress on self-esteem, job satisfaction, and turnover ntention. Journal of Transnational Management, 21(1), 29-39.

Yukl, G. (2012). Effective leadership behavior: What we know and what questions need more attention. Academy of Management Perspectives, 26(4), 66-85. https://doi.org/10,5465/amp.2012.0088

Yuwono, T., Wiyono, N., Asbari, M., Novitasari, D., \& Silitonga, N. (2020). Analisis Pengaruh Efektivitas Kepemimpinan Transformasional dan Kesiapan untuk Berubah terhadap Kinerja Karyawan Wanita di Masa Pandemi Covid-19. Jurnal lmiah Mahasiswa Ekonomi Manajemen, 5(3), 615-632. http://www.jim.unsyiah.ac.id/EKM/article/view/15502

Zaman, M. N., Novitasari, D., Goestjahjanti, F. S., Fahlevi, M., Nadeak, M., Fahmi, K., Setiawan, T., \& Asbari, M. (2020a). Effect of Readiness to Change and Effectiveness of Transformational Leadership on Workers ' Performance during Covid-19 Pandemic. Solid State Technology, 63(1s), 185-200 http://www.solidstatetechnology.us/index.php/JSST/article/view/708 
455 Stres Kerja dan Turnover Intention di Era Revolusi Industri 4.0: Adakah Harapan pada Kepemimpinan Transformasional? - Dewiana Novitasari, Muhammad Johan, Multi Nadeak, Admiral, Masduki Asbari DOI: https://doi.org/10.31004/edukatif.v4i1.1880

Zaman, M. N., Novitasari, D., Goestjahjanti, F. S., Fahlevi, M., Nadeak, M., Fahmi, K., Setiawan, T., \& Asbari, M. (2020b). Effect of Readiness to Change and Effectiveness of Transformational Leadership on Workers' Performance during Covid-19 Pandemic. Solid State Technology, 63(1s), 185-200 